ORIGINAL ARTICLE

\title{
Bone Loss During the Acute Stage Following Burn Injury: Is It Local or Systemic?
}

\author{
PD Analan ${ }^{1}$, B Leblebici ${ }^{1}$, M Adam $^{1}$, Ç Sarıtürk ${ }^{2}$
}

\begin{abstract}
Objective: To examine post-burn bone loss and determine whether it was local or diffuse.

Methods: Thirty-six patients with burn injuries were investigated, and the total body surface area of the burns and their locations were recorded. The bone mineral densities of the lumbar 1-4 vertebrae, bilateral distal forearm, and bilateral proximal femur of the patients were recorded, and these were compared with the measurements of the non-burnt extremity.

Results: No statistically significant correlations existed among the total body surface area of the burns, their severity and the z-scores. In addition, when comparing the z-scores of the burnt extremity with those of the non-burnt extremity, no statistically significant difference was found $(\mathrm{p}>0.05)$.

Conclusion: In this study, a remarkable decrease in bone mass occurred during the second month following the burn injuries. The post-burn bone loss could not be correlated with the severity of the burns, but these injuries caused systemic bone loss.
\end{abstract}

Keywords: Bone loss, bone mineral density, burn injury

\section{La pérdida ósea durante la etapa aguda después de una lesión por quemaduras, ¿es local o sistémica?

\author{
PD Analan ${ }^{1}$, B Leblebici¹, M Adam¹, Ç Sarıtürk ${ }^{2}$
}

\begin{abstract}
RESUMEN
Objetivo: Examinar la pérdida ósea después de una quemadura y determinar si era local o difusa.

Métodos: Se investigó a 36 pacientes con lesiones por quemaduras y se registró el área total de la superficie del cuerpo con quemaduras y sus ubicaciones. Las densidades minerales óseas de las vértebras lumbares 1-4, del antebrazo distal bilateral, y del fémur proximal bilateral de los pacientes, fueron registradas y comparadas con las mediciones de la extremidad sin quemaduras.

Resultados: No existieron correlaciones estadisticamente significativas entre el área total de la superficie corporal de las quemaduras, su severidad y las puntuaciones z. Además, al comparar las puntuaciones $z$ de la extremidad quemada con las de la extremidad no quemada, no se encontró ninguna diferencia estadísticamente significativa $(\mathrm{p}>0.05)$.
\end{abstract}

From: ${ }^{1}$ Department of Physical Medicine and Rehabilitation, Adana Research and Education Center, Faculty of Medicine, Baskent University, Adana, Turkey and ${ }^{2}$ Department of Biostatistics, Adana Research and Education Center, Faculty of Medicine, Baskent University, Adana, Turkey.
Correspondence: Dr PD Analan, Department of Physical Medicine and Rehabilitation, Adana Research and Education Center, Faculty of Medicine, Baskent University, Kazım Karabekir Cad 4227 Sok No.37 Yüreğir, Adana, Turkey. Email: doruk.pinar@gmail.com 
Conclusión: En este estudio, se observó la ocurrencia de una disminución notable de la masa ósea durante el segundo mes tras las lesiones de la quemadura. La pérdida ósea posterior a las quemaduras no se pudo correlacionar con la severidad de las quemaduras, pero estas lesiones por quemadura causaron pérdida sistémica del hueso.

Palabras clave: Pérdida ósea, densidad mineral ósea, lesión por quemadura

West Indian Med J 2018; 67 (3): 230

\section{INTRODUCTION}

Thermal injury causes changes in bone metabolism, but the aetiopathogenesis of this mechanism has not been fully understood (1). Several possible mechanisms and mediators may be involved in the skeletal response to this type of injury, including reduced skeletal loading, bone marrow suppression, and changes in cytokine and mineral homeostasis, such as hypocalcaemia, hypercalciuria secondary to hypoparathyroidism, and vitamin D deficiency (2-7).

The result of these pathogenetic mechanisms that develop after burns can cause skeletal metabolism changes that lead to an increased incidence of bone loss. In thermally injured children and adults, there is a dramatic decrease in bone formation that is accompanied by an increase in or maintenance of bone resorption $(2,5)$. The bone loss is manifested by the post-burn loss of total body bone mineral content as determined by dual-energy $\mathrm{X}$-ray absorptiometry (DEXA) and intraoperative iliac crest bone biopsies $(2,3)$.

Even with all of these data, the effects of thermal injuries on bone and calcium metabolism are still not fully understood. Furthermore, there are no data available regarding whether osteoporosis is limited to the burn area or not, and knowing whether this bone disease is local or systemic could result in beneficial treatment applications for burn patients. Therefore, the aim of this study was to determine whether post-burn bone loss was local or diffuse.

\section{SUBJECTS AND METHODS}

This retrospective study was conducted using 36 burn patients ( 9 men and 27 women, with an age range of 20-50 years) who were treated at the in-patient Burn Unit of Adana Research and Education Center, Baskent University, Turkey, and was approved by its Ethics Committee.

Patients with thyroid disorders, chronic liver or kidney disease, epilepsy, rheumatic diseases, diabetes mellitus, a history of osteoporosis before the burn injury, or those with a history of long-term steroid or anabolic drug use that could affect bone metabolism were excluded from the study. Patients were evaluated according to the percentage of total body surface area (TBSA) that was burnt and the localization of the burn. A TBSA burn rate of $\geq 25 \%$ was accepted as a severe burn (8).

Dual-energy X-ray absorptiometry was used to measure bone mass (Hologic QDR4500A, Hologic Inc, Bedford, Massuchusetts, USA). The bone mineral densities of the L1-L4 vertebrae, bilateral distal forearm, and bilateral proximal femur of the patients were recorded. Bone loss was assessed with a z-score of the burnt extremity, and this was then compared with that of the non-burnt extremity. A z-score of $<-1$ was accepted as an indicator of osteoporosis, and a score between 0 and -1 was accepted as an indicator of osteopaenia.

\section{Statistical analysis}

Statistical analysis was performed using the Statistical Package for the Social Sciences (SPSS) version 17.0 for Windows software program (SPSS Inc, Chicago, Illinois, USA). The categorical measurements were expressed using numbers and percentages. Continuous measurements were given as mean and standard deviation (and if required, mid-value and minimum-maximum), calculated via a Chi-square test or Fisher's exact test and added to the descriptive statistics. These were then compared with the categorical variables. Statistical significance was set at 0.05 .

\section{RESULTS}

Table 1 shows the patients' characteristics and Table 2 the aetiology of the burns.

When the burnt extremity was compared with the non-burnt extremity, there was no statistically significant difference between the two z-scores $(p>0.05)$. These results are shown in Table 3.

Additionally, there was no statistically significant difference between the TBSA burn rate and the z-scores $(p>0.05)$. According to the $z$-scores $(p>0.05)$, there 
Table 1: Characteristics of the study population $(\mathrm{n}=36)$

\begin{tabular}{ll}
\hline Characteristics & Values \\
\hline $\begin{array}{l}\text { Age (years): mean } \pm \text { standard deviation, } \\
\text { minimum-maximum }\end{array}$ & $34.03 \pm 11.13,20-50$ \\
$\begin{array}{l}\text { Gender (female/male): n, } \% \\
\text { Time since burn injury (days): mean } \pm \text { standard }\end{array}$ & $41.86 \pm 42.86,13-273$ \\
$\begin{array}{l}\text { deviation, minimum-maximum } \\
\text { Percentage of total body surface area that was }\end{array}$ & $12 / 24,33.3 \% / 66.7 \%$ \\
burnt (below 25\%/above 25\%): $n, \%$ & \\
\hline
\end{tabular}

Table 2: Aetiology of the burns of the study population $(\mathrm{n}=36)$

\begin{tabular}{ll}
\hline Characteristics & n (\%) \\
\hline Electricity & $13(36.1 \%)$ \\
Flames & $17(47.2 \%)$ \\
Hot liquid & $3(8.3 \%)$ \\
Chemicals & $3(8.3 \%)$ \\
\hline
\end{tabular}

Table 3: Comparison between the z-scores of the burnt extremity and the non-burnt extremity

\begin{tabular}{|c|c|c|c|c|}
\hline Characteristics & $\begin{array}{l}\text { Normal } \\
\text { n }(\%)\end{array}$ & $\begin{array}{l}\text { Osteopaenia } \\
\text { n }(\%)\end{array}$ & $\begin{array}{l}\text { Osteoporosis } \\
\text { n }(\%)\end{array}$ & $p$-value \\
\hline Patient with a burn on the right upper extremity & $8(25 \%)$ & $9(28.1 \%)$ & $15(46.9 \%)$ & 0.108 \\
\hline Patient without a burn on the right upper extremity & 0 & $2(100 \%)$ & 0 & \\
\hline Patient with a burn on the left upper extremity & $6(21.4 \%)$ & $8(28.6 \%)$ & $14(50 \%)$ & 0.370 \\
\hline Patient without a burn on the left upper extremity & 0 & $3(50 \%)$ & $3(50 \%)$ & \\
\hline Patient with a burn on the trunk & $8(28.6 \%)$ & $8(28.6 \%)$ & $12(42.9 \%)$ & 0.498 \\
\hline Patient without a burn on the trunk & $2(25.0 \%)$ & $4(50.0 \%)$ & $2(25.0 \%)$ & \\
\hline Patient with a burn on the right lower extremity & $11(45.8 \%)$ & $7(29.2 \%)$ & $6(25.0 \%)$ & 0.487 \\
\hline Patient without a burn on the right lower extremity & $7(58.3 \%)$ & $4(33.3 \%)$ & $1(8.3 \%)$ & \\
\hline Patient with a burn on the left lower extremity & $11(47.8 \%)$ & $8(34.8 \%)$ & $4(17.4 \%)$ & 0.308 \\
\hline Patient without a burn on the left lower extremity & $7(58.3 \%)$ & $5(41.7 \%)$ & 0 & \\
\hline
\end{tabular}

was also no statistically significant difference between the patients whose TBSA burn rate was less than $25 \%$ and those with a rate higher than $25 \%$.

\section{DISCUSSION}

Although the aetiology of bone loss due to burn injuries is not clearly known, several complex mechanisms (such as bone-active proinflammatory cytokines, systemic inflammation, stress, endocrine response, increased resorption due to the catabolic period, changes in vitamin D and calcium metabolism, biochemically abnormal skin, and reduced formation due to immobilization) have been considered as possible causes $(2,5-11)$.

Numerous studies on both animals and humans have demonstrated that reduced mechanical loading is associated with decreased bone formation and bone mass as well as increased resorption. Reduced skeletal loading, such as immobilization, following any type of injury may be a significant contributing factor to bone loss (6). On the other hand, a study of adult patients with greater than $50 \%$ TBSA burn injuries showed that this population exhibited lower bone formation rates than age-matched controls and volunteers who were subjected to seven days of bed rest (7). Additionally, Leblebici et al (5) found that decreased bone mineral density after a burn was not correlated with functional status. These findings support the idea that skeletal underloading is more responsible for post-burn bone loss than any results achieved with sustained bed rest $(5,7)$. In our study, immobilized patients were evaluated. For this reason, we were not sure about the impact of functional status on bone loss following burn injury. However, we hypothesized that bone loss may be precipitated with immobilization in patients with burn injury.

Our study measured the decrease in bone mineral density at the burnt extremity during the second month after the injury, and the results revealed bone loss. This supports the hypothesis that bone loss begins soon after a thermal injury. Klein et al showed that intraoperative iliac crest bone biopsies in adults demonstrated reduced bone formation approximately three weeks after a burn injury (12). Edelman et al used a murine burn model to show that significant changes in bone density could be measured within 10 days after a burn injury (13). Conversely, Edelman et al also studied 29 children and adults with thermal injuries and found no statistically significant changes in bone mineral density in muscle and fat mass during the acute period following their injuries (14). However, they did find significant changes in muscle mass, fat mass and bone mineral density at 90 , 138 and 131 days post-burn, respectively (14). Leblebici et al measured bone mineral density in a group of patients and found bone loss during the first post-burn month in the left distal forearm and in the L1-L4 vertebrae. In 
addition, biochemical changes were also found within the same period (8).

While the significance of any observed differences in the static parameters of bone histomorphometry is uncertain, it should be kept in mind that these static parameters are slower to change than dynamic parameters and that mineral apposition and bone formation rates are uniformly negligible in the burn population. Since the static parameters change more slowly, the differences when compared with normal, as denoted by the z-scores, may not be as dramatic, given the proximity of the bone biopsy to the burn injury (10). In this study, we used DEXA as the static parameter of bone loss. If we had used dynamic parameters, we would have found more specific results of bone loss, eg bone mineral density.

It is assumed that bone loss will be higher in patients who have a relatively high percentage of TBSA that was burnt. In the studies that focussed on children with a TBSA burn rate of greater than $40 \%$ who suffered bone mineral loss, a reduction in the 25 -hydroxyvitamin D level, along with an increased risk of fracture and osteoporosis at the beginning of adulthood, was observed $(14,15)$. Miller et al found that the severity of bone loss appeared to be related to the severity of the injury (6), whereas Leblebici et al determined that the severity of bone loss was not correlated with the TBSA burn rate or the severity of the burn injury (16). Our results were similar to the study by Leblebici et al as we found no correlation between bone loss and the TBSA burn percentage. In addition, when we compared the patients with a TBSA burn rate of less than $25 \%$ with those with a rate of more than $25 \%$, we observed no statistically significant differences. This shows that osteoporosis occurs because of much more complicated mechanisms.

In our study, osteoporosis was observed in the patients with a TBSA burn percentage of $>33.5 \%$. However, the values were not statistically significant since their sensitivity and specificity were accepted as $50 \%$. Hence, this statistical value was not utilized to plan any osteoporosis treatment. Further studies are necessary to determine higher cut-off values with higher sensitivity and specificity. However, it might be possible for patients with burn rates higher than this level to undergo treatment for osteoporosis.

References in the literature indicate that post-burn osteoporosis should be considered as systemic (14-16). However, there is no study that has definitively proven a connection between bone loss and local or systemic responses. In our study, no statistically significant differences were observed between the burnt and non-burnt extremities regarding the values of bone mineral density.
This could be because osteoporosis was not only localized, but it also caused systemic bone loss by affecting the non-burnt parts of the body.

One of the limitations of this study is that we included a relatively small number of burn patients. Furthermore, the measurements of the non-dominant extremity, distal forearm densities could not be compared. Osteoporosis following a burn injury is known as secondary osteoporosis, and this is evaluated by using this type of measurement. However, the patient population in our study was not sufficient to compare these values statistically. Therefore, it is our hope that new studies will be undertaken to evaluate the results of the non-dominant extremity, distal forearm bone densities since the results could yield valuable information for treating secondary osteoporosis.

\section{REFERENCES}

1. Klein GL, Kikuchi Y, Sherrard DJ, Simmons DJ, Biondo N, Traber DL. Burn-associated bone disease in sheep: roles of immobilization and endogenous corticosteroids. J Burn Care Rehabil 1996; 17: 518-21.

2. Klein GL. Burn-induced bone loss: importance, mechanisms, and management. J Burns Wounds 2006; 5: 32-8.

3. Klein GL, Wimalawansa SJ, Kulkarni G, Sherrard DJ, Sanford AP, Herndon DN. The efficacy of the acute administration of pamidronate on the conservation of bone mass following severe burn injury in children: a double blind, randomized, controlled study. Osteoporos Int 2005; 16: 631-5.

4. Klein GL, Chen TC, Holick MF, Langman CB, Price H, Celis MM et al. Synthesis of vitamin D in skin after burns. Lancet 2004; 363: 291-2.

5. Leblebici B, Sezgin N, Ulusan SN, Tarim AM, Akman MN, Haberal MA. Bone loss during the acute stage following burn injury. J Burn Care Res 2008; 29: 763-7.

6. Miller SC, Bowman BM, Siska CC, Shelby J. Effects of thermal injury on skeletal metabolism in two strains of mice. Calcif Tissue Int 2002; 71: 429-36.

7. Shea JE, Bowman BM, Miller SC. Alterations in skeletal and mineral metabolism following thermal injuries. J Musculoskelet Neuronal Interact 2003; 3: 214-22.

8. Esselman PC, Moore ML. Issues in burn rehabilitation. In: Braddom RL, ed. Physical medicine and rehabilitation. Philadelphia: Saunders; 2007: 1399-413.

9. Helm PA, Kowalske K, Head M. Burn rehabilitation. In: Delisa JA, ed. Physical medicine and rehabilitation. Philadelphia: LipppincottWilliams \& Wilkins; 2005: 1867-89.

10. Klein GL, Bi LX, Sherrard DJ, Beavan SR, Ireland D, Compston JE et al. Evidence supporting a role of glucocorticoids in short-term bone loss in burned children. Osteoporos Int 2004; 15: 468-74.

11. Klein GL. Burns: where has all the calcium (and vitamin D) gone? Adv Nutr 2011; 2: 457-62.

12. Klein GL, Herndon DN, Rutan TC, Sherrard DJ, Coburn JW, Langman $\mathrm{CB}$ et al. Bone disease in burn patients. J Bone Miner Res 1993; 8: $3337-45$.

13. Edelman LS, Shao W, Miller S, Bowman B, Morris SE, Shelby J. The 1997 Lindberg Award. Effects of burn injury on bone and growth in a mouse model. J Burn Care Rehabil 1997; 18: 483-9.

14. Edelman LS, McNaught T, Chan GM, Morris SE. Sustained bone mineral density changes after burn injury. J Durg Res 2003; 114: 172-8.

15. Klein GL, Wolf SE, Goodman WG, Phillips WA, Herndon DN. The management of acute bone loss in severe catabolism due to burn injury. Horm Res 1997; 48: 83-7.

16. Leblebici B, Adam M, Tarım AM, Akman NM, Haberal MA. Bone loss in the acute stage following burn injury - original investigation. Turkish Journal of Osteoporosis 2007; 13: 33-6. 